Савуляк Вікторія, старший викладач кафедри загальної психології та психодіагностики Рівненського державного гуманітарного університету, ORCID iD: 0000-0002-5216-6737 DOI https://doi.org/10.35619/prap_rv.vi13.132

\title{
ОСОБЛИВОСТІ СОЦІАЛЬНОГО СПРИЙМАННЯ У ПІДЛІТКОВОМУ ВІЦІ
}

\begin{abstract}
Анотація. У статті наголошується на актуальності науково-психологічних досліджень різних аспектів соціально-перцептивних процесів, які є вагомим чинником (не-)конструктивності в усіх видах життєдіяльності людини. Предметом власного емпіричного дослідження автора стали особливості рефлексії (як механізму сочіальної периепції) підлітків, точність розуміння ними невербальної комунікації та соціальнопериептивні установки щодо інших людей. У статті визначено основні поняття, обтрунтовано вибір психодіагностичних методик. Результати емпіричного дослідження засвідчили переважання змішаного типу рефлексії та доволі значну частку школярів із системною рефлексією і низьку - із квазірефлексією (із тенденцією до зменшення $з$ віком). Низьких балів (негативної установки) при визначенні соціально-перцептивної установки не відзначено; переважає також середній рівень. Констатовано часткове покращення з віком розуміння невербальної комунікачії (міміки). Отримані результати дозволяють деталізувати завдання психотренінгової роботи з розвитку комунікативної компетентності підлітків через формування їхніх соціально-перцептивних умінь та відповідних установок.
\end{abstract}

Ключові слова: соціальна перцепція, сочіально-перцептивна установка, функції соціально-периептивної установки, невербальна комунікація, системна рефлексія, інтроспекція, квазірефлексія, підлітки.

Постановка проблеми. В умовах глобалізації соціально-економічних i політичних процесів, які відбуваються в сучасному суспільстві і мають подекуди деструктивний характер, однією з найбільш значних видається проблема оптимізації спілкування і міжособистісних відносин. (Щодо спілкування варто говорити про два ряди його функцій: соціальних і власне соціально-психологічних, але практична соціальна психологія аналізує переважно другі; проблеми ж, пов'язані з розумінням спілкування у більш широкому контексті, не ставляться. Це пояснюється тією обставиною, що, згідно з усталеною традицією, ці проблеми досліджуються в руслі інших дисциплін, зокрема, в соціології.)

Необхідність взаєморозуміння, вироблення спільної думки, прийняття взаємовигідних рішень є умовами спільної життєдіяльності і виживання людей. На жаль, даний підхід на сьогодні не є домінуючим. Недовіра, прагнення до протистояння, критичне ставлення до інших і очікування негативізму у відповідь настільки поширені в світі, що можуть виходити за межі здорового глузду. У зв'язку з цим актуальним стає виявлення шляхів і механізмів, що зумовлюють і забезпечують характер взаємодії людей. В якості одного з таких механізмів, що визначають основу поведінки, в тому числі і комунікативної, слід розглядати психологічні установки, і перш за все ті, що обумовлюють характер / тип сприйняття інших, тобто результат соиіальної периепиії (соціального сприймання) - процесу, що виникає при стосунках людей і полягає у сприйнятті, вивченні, розумінні й оцінці людьми соціальних об'єктів. 
Аналіз останніх досліджень 3 проблеми. Результати досліджень ролі соціальної перцепції в життєдіяльності людини представлено у роботах багатьох зарубіжних та вітчизняних авторів. Вивчалися, зокрема: основні механізми соціальної перцепції ідентифікація, емпатія, децентрація, егочентризм, атракція, рефлексія, стереотипізація, каузальна атрибуція (Хайдер, Ньюком, Фестингер, Канеман, Андреєва, Зімбардо, Бодальов, Жуков); проблеми розвитку соціально-перцептивних умінь у суб'єктів міжособистісного сприймання та підвищення його адекватності (Бандура, Уолтерс, Келлі, Аронсон, Петровська, Яценко, Агєєв, Ємельянов); ефекти соціальної перцепції і прояв при цьому соціальних установок суб'єкту сприймання (Пратканіс, Грюнвальд, Снайдер, Джонс, Росс, Селігман, Войскунский, Дубовицька); особливості міжособистісного сприймання в різних сферах життєдіяльності людини та у різні вікові періоди (Теджфел, Шериф, Коломінський, Бодальов, Роджерс, Донцов, Гозман, Максименко, Швалб, Чепелєва, Семиченко, Худякова).

Попри це, зважаючи на «проблеми вивчення соціально-перцептивних процесів, обумовлені неможливістю перевірки точності, глибини, диференційованості та інших характеристик соціальної перцепції шляхом прямого зіставлення 3 даними об'єктивних методик» (Худякова, 2014, с.193), залишається чимало недостатньо досліджених аспектів.

Мета статті полягає у висвітленні результатів емпіричного дослідження особливостей соціальної перцепції (соціально-перцептивної установки, рефлексії, розуміння невербальних складових комунікації) у підлітковому віці.

Виклад основного матеріалу дослідження. В історії соціальної психології впровадженню самого терміну «соціальна перцепція» науковці завдячують американському психологові Дж. Брунеру, який констатував, що сприйняття зумовлене не лише об'єктивнофізичними (суто сенсорними) характеристиками об’єкту сприйняття, але і прихованими соціальними чинниками, до яких автор відносив минулий досвід суб'єкту, його цілі, наміри, рівень значущості ситуації тощо (Брунер, 2008).

Характер інформації від соціального об'єкту може бути різним: міра об'єктивності може варіюватися від нарочито байдужого тону викладу до включення в сам текст повідомлення явних елементів переконання. Варіант повідомлення задається комунікатором, тобто тією особою, від якої виходить інформація. Передача будь-якої інформації можлива лише за допомогою знаків, точніше, знакових систем.

На різних вікових етапах онтогенезу здатності соціальної периепиії людини набувають розвитку (Москаленко, 2008, с.479-506). Кожен віковий період характеризується інтенсивним розвитком не лише інтелектуальних здібностей особистості, а й міжособистісної взаємодії, уявлень про особистість і мотиви поведінки.У молодшому і середньому дошкільному віці сприймання об'єкту відбувається на основі опису його конкретних дій та оцінки. У старшому дошкільному і молодшому шкільному віці базується на виділенні окремих психологічних властивостей; починаючи 3 підліткового віку - на основі здатності до побудови цілісного психологічного портрету. У ранньому юнацькому віці міжособистісна перцепція суб'єктів, на думку вчених, характеризується збільшенням кількості описових категорій, зростанням їх гнучкості та визначеності у процесі їх використання, підвищенням рівня вибірковості, послідовності, складності та інтегрованості інформації. Успішніше визначають різні психічні стани і міжособистісні відносини ті люди, що мають більш високий рівень соціального інтелекту. Соціальний інтелект є тією здатністю, яка має еволюційну значущість для людини, навички спілкування здобуваються людиною протягом життя та залишаються практично до самої старості.

Суттєво впливають на процес міжособистісного пізнання статеві відмінності. Так, недавно проведене Дем'янюк і Косарєвою дослідження особливостей наявних у чоловіків і жінок гендерних установок і стереотипів, а також гендерних відмінностей у сприйманні соціальної реальності (на вибірці студентів III-V курсів) вкотре надало підтвердження поширеному побутовому уявленню, що соціальна перцепція краще розвинута в осіб 3 фемінними властивостями (2018). Процес міжособистісного розуміння тісно пов'язаний 3 емоційною сферою. Уміння сприйняти почуття іншої людини як власні, здатність до емоційного відгуку - необхідний компонент спілкування та специфічний засіб пізнання 
людини людиною. Відмінність між почуттями та змістом спілкування не завжди можна простежити. Розуміння та адекватна відповідь на емоційні вияви важливі тому, що в спілкуванні люди, як правило, обмінюються тим, що має для особистості смисл.

Продуктивність спілкування і розуміння залежить у таких випадках не тільки від фактичної інформації, а й від установок, почуттів, емоційних виявів. Зокрема, можна говорити про т.зв. соиіально-периелтивну установку щодо інших людей, при цьому необхідно розрізняти поняття «соціальна установка» і «перцептивна установка». Поняттю соціальної установки в західній психології відповідає термін «аttitude». У соціальну психологію термін «атитюд» було введено у 1918 р. польськими психологами Томасом і Ф. Знанецьким, при вивченні адаптації польських селян, які емігрували з Свропи до США. За їхнім визначенням, соціальна установка - це психологічне переживання індивідом значущості або цінності соціального об'єкту, і завжди є чиїмось станом, що містить ставлення до когось / чогось. Розглядаючи проблему регуляції соціальної поведінки в якості ключової для соціальної психології, вони вважали, що соціальна психологія - це наука про атитюди, оскільки саме соціальна (а не індивідуальна чи загальна) психологія покликана вивчати «суб'єктивну сторону культури». Перцептивна установка - це готовність сприймати те, що ви очікуєте побачити, і не диференціюється за об'єктами (Асмолов, 1977).

Соціально-перцептивна установка визначається як «схильність суб'єктів спілкування сприймати, оцінювати і діяти один щодо одного певним чином» (Дубовицька, 2014, с.253). Соціально-перцептивна установка практично завжди проявляється у суб'єктів в ситуаціях спілкування та міжособистісних відносин, виступаючи однією зі складових когнітивного компоненту культури ставлення людей один до одного. На відміну від стереотипів, які мають глобальний характер (поширюються не тільки на сприйняття людей 3 урахуванням їх національності, професії, релігійної приналежності тощо, але й на оцінку явищ), соціальноперцептивна установка має більш приватний (проявляється щодо людей) і більш лабільний характер (залежить від обставин і ситуації).

Така установка формується на основі попереднього досвіду спілкування з людьми і виконує наступні функції:- соціально пристосувальну (утилітарну); когнітивну: спрощує взаємну орієнтацію на основі сформованої думки один про одного; експресивно-оцінну: виявляється в специфічних емоційно забарвлених думках і висловлюваннях на адресу один одного; психологічного захисту: оберігає суб'єктів від внутрішніх конфліктів, підтримує їхню самооцінку. У ситуації недовіри до світу людина живе з уявленням про те, що світ і оточення - злі, і навряд чи від них можна очікувати чогось доброго, в силу чого у всіх життєвих ситуаціях вона очікує від інших проявів негативізму на свою адресу і готується до захисних дій у відповідь. Накопичуючи певний життєвий досвід, людина може 3 часом прийти до розуміння того, що світ і інші люди можуть бути добрими до неї та з ними можна мати справу, в тому числі проявляти у відповідь доброзичливе ставлення, але подібна зміна соціально-перцептивної установки може розтягнутися на багато років.

Безперечно, людині необхідно проявляти обережність у відносинах, розуміти, що люди можуть бути різними. Ніколи не буває зайвим дізнатися додаткову інформацію про людину 3 різних джерел, постаратися знайти спільні точки дотику і вже потім приймати рішення про (не-)можливість і характер подальших відносин. На жаль, люди часто від початку проявляють негативну соціально-перцептивну установку щодо оточення, і це ускладнює конструктивну взаємодію, заважає їм як в особистих відносинах, так і в спільній діяльності. В емпіричному дослідженні нами було застосовано методику "Діагностика соціально-периептивної установки людини щзодо інших людей» (розробники: Дубовицька, Тулітбаева, Шашков), процедура проведення якої передбачає виявлення згоди-незгоди досліджуваних із запропонованими прислів'ями.

Відображаючи узагальнений людський досвід, прислів'я формують культуру поведінки та стиль життя (наприклад: «Не взявшись за сокиру, хати не зробиш»; «Курчат рахують восени»; «Шила в мішку не сховаєш»), допомагають людині зрозуміти і пояснити поведінку інших людей, в тому числі й таку, яка не завжди є конструктивною чи позитивною на думку оточення («Яблуко від яблуні недалеко падає»; «На злодієві шапка горить»), а також 
формують певні переконання, погляди, які можуть допомогти уникнути несподіваних неприємностей («Від добра добра не шукають»). У ряді випадків вони мають відтінок негативізму і зловтіхи («Людина людині - вовк», «Добро має бути з кулаками», «Гарно каже, а сам зло чинить»). Знайомство людини 3 прислів'ям або актуалізує у неї відповідний життєвий досвід і тоді вона погоджується із прислів'ям, або суперечить ії життєвому досвіду, внутрішнім переконанням, і тоді людина не погоджується з ним. Тим самим, згода $з$ одними прислів'ями та незгода з іншими дозволяе виявити притаманні людині внутрішні установки, які зумовлюють іiі поведінку в певних ситуаціях. Традиційно розрізняють вербальну (використовується мова як знакова система) і невербальну комунікацію (використовуються різні немовні знакові системи). Усі системи невербальної комунікації відіграють велику допоміжну (а іноді - самостійну) роль у комунікативному процесі. Методика ідентифікації емочій людини за фото облич (автор - американський психолог Екман) дозволила визначити точність розуміння підлітками міміки як важливої невербальної системи комунікації.

Особливості рефлексії досліджуваних визначалися за допомогою тесту-опитувальника «Диференційний тип рефлексії» (автори: Леонтьев, Лаптєва, Осін, Саліхова). Вибірка дослідження становила 50 осіб; у неї увійшли школярі віком 12-13 років (7-й клас) та 14-15 років (9-й клас). За тестом-опитувальником «Диференційний тип рефлексії» було отримано такі результати: у трьох семикласників і трьох дев'ятикласників було виявлено тип рефлексії «системна рефлексія», а це може свідчити про те, що ці учні здатні до самоаналізу, вони вміють аналізувати свою поведінку як зі своєї сторони, так і ніби збоку, очима інших. 4 семикласника та 3 дев'ятикласника мають тип рефлексії «інтроспекція», а це може вказувати на те, що вони більше зосереджені на своїх переживаннях, внутрішніх станах, що не сприяє налагодженню ефективної взаємодії $з$ оточенням. 4 учні 7-го класу і 2 учні 9-го класу мають тип рефлексії «квазірефлексія», що може вказувати на низьку осмисленість життя, негативне самоставлення. Таким людям притаманні спекулятивні, резонерські міркування, марні фантазії; уникання неприємної ситуації, реальне вирішення якої не є очевидним; існує ризик невротизації. У 14-ти учнів 7-го класу (56\%) та 17-ти учнів 9-го класу (68\%) виявлено змішаний тип рефлексії, що може бути свідченням вікових психологічних особливостей: через перехідний етап особистісного розвитку та об'єктивну нестачу життєвого досвіду недостатній рівень системної рефлексії. Порівняльні результати ідентифікації емоцій представлено на рис.1.

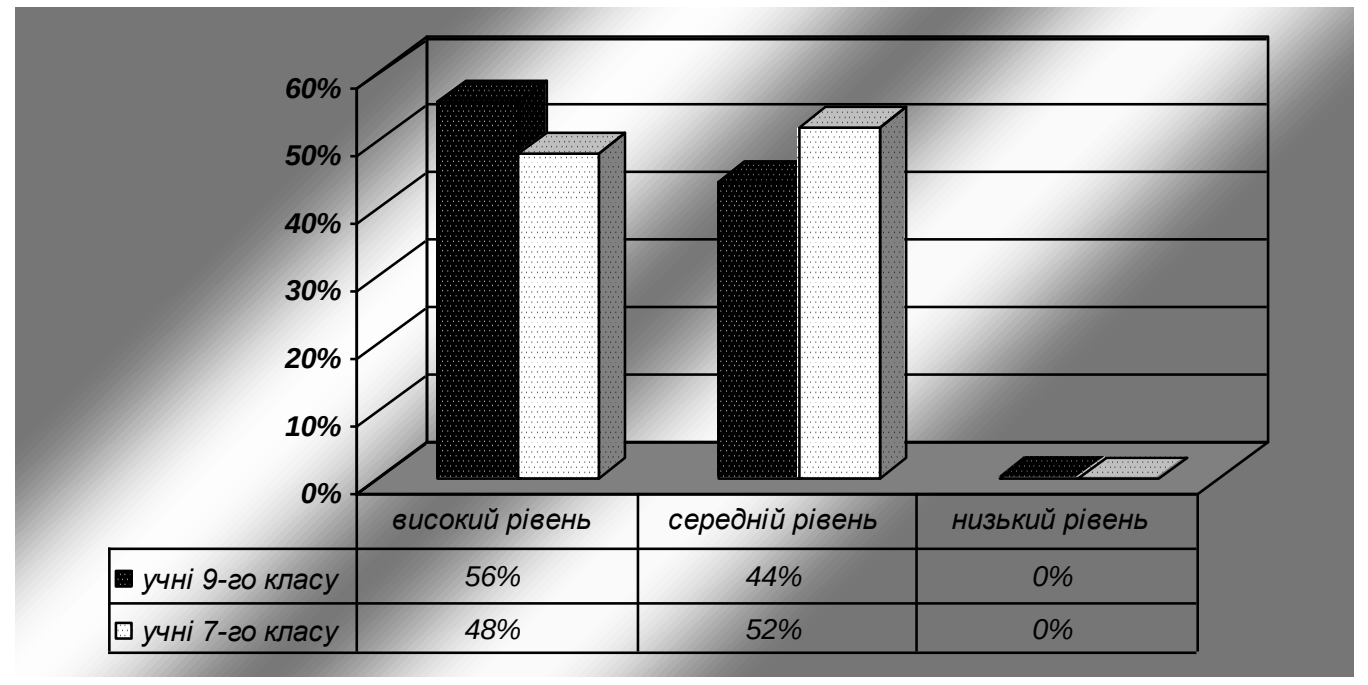

\section{Рис.1. Результати учнів 7-го та 9-го класів за методикою ідентифікації емоцій за фото П. Екмана}

Продіагностувавши соціально-перцептивні установки, маємо результати: 19 учнів 7-го класу (76\%) i 18 учнів 9-го класу (72\%) мають середні показники соціальноперцептивної установки щодо інших людей, а це може вказувати на їхнє бажання до співпраці, відкритість, щирість, прагнення мати близькі стосунки в яких довіряють один одному. 6 семикласників та 7 дев'ятикласників отримали високі показники, а це може 
свідчити про те, що вони готові довіряти людям, допомагати їм. Вони мають здатність бачити позитивні якості інших, вірять в те, що люди можуть розвиватися та досягати успіхів і високих результатів у своїй діяльності. Вони емпатійні, доброзичливі, готові підтримати в будь-яку хвилину, намагаються нікого не критикувати. Негативної соціально-перцептивної установки виявлено не було, i це, безумовно, є гарним результатом. За допомогою коефіцієнту парної кореляції Пірсона було встановлено залежності між показниками соціально-перцептивних установок людей один щодо одного та типами рефлексії (системна рефлексія, інтроспекція, квазірефлексія). Існує слабо виражена зворотна кореляційна залежність між показниками соціальноперцептивної установки людей один щодо одного та шкалами «системна рефлексія», «інтроспекція» (відповідно: $\mathrm{r}=-0,06384 ; \mathrm{r}=-0,07417$ ) та зворотна статистично значуща залежність між показниками соціально-перцептивної установки людей один щодо одного та шкалою «квазірефлексія» $(\mathrm{r}=-0,55225)$, що підтверджує непродуктивний, захисний характер цього типу рефлексії.

Висновки та перспективи подальших розвідок. Соціальна перцепція характеризується емоційним переживанням щодо об'єкту сприйняття, певною заангажованістю суб'єкту соціально-перцептивної діяльності. Здатність визначати стан іншої людини, інтерпретувати іiї як особистість розвивається через накопичення досвіду спілкування з іншими людьми, аналіз та узагальнення цього досвіду. Соціальноперцептивні установки, які при цьому формуються, можуть бути позитивними, негативними і нестійкими (невизначеними); проявлятися у ставленні до партнерів у взаємодії, а також можуть мати глобальний характер, проявлятися в цілому до людей і світу, накладаючи відбиток на всю поведінку людини. Усвідомлення особливостей своєї соціально-перцептивної установки і здатність керувати нею є однією з важливих умов як профілактики, так і психокорекції поведінки у міжособистісній взаємодії, вирішення конфліктів. Розвиток комунікативної компетентності у цьому напрямку варто поєднувати із розвитком здатності до рефлексії у іiі конструктивному варіанті - до системної рефлексії. Перспективним напрямком подальших досліджень нам видається з'ясування взаємозв'язку типів рефлексії з іншими індивідуально-психологічними характеристиками, з урахуванням вікових особливостей цього взаємозв’язку.

\section{СПИСОК ПОСИЛАНЬ}

Асмолов, А. Г. (1977). О соотношении понятия установки в общей и социальной психологии. Г. М. Андреева, Н. Н. Богомолова (Ред.), Теоретические и методологические проблемь социальной психологии. (с. 143-163). Москва: Издательство Московского университета.

Брунер, Дж. (2008). Психология познания. За пределами непосредственно воспринимаемой информации. Москва: Директмедиа Паблишинг.

Дем’янюк, О. Б., Косарєва, О. І. (2018). Особливості соціальної перцепції у студентської молоді (ґендерний аспект). Психологічний часопис, 4 (14), 54-67.

Дубовицкая, Т. Д. (2014). Социально-перцептивная установка: понятие, функции, виды. European social science journal, 1-1(40), 252-256. Взято 3 https://elibrary.ru/item.asp?id=21540986

Москаленко, В. В. (2008). Соціальна психологія. Київ: ЦУЛ.

Худякова, В. І. (2014). Дослідження характеристик і детермінант соціальної перцепції у діяльності менеджера закладу. Науковий вісник Миколаӥвського державного університету ім. В. О. Сухомлинського. Психологічні науки, 2.12 (103), 93-97.

\section{REFERENCES}

Asmolov, A. G. (1977). O sootnoshenii ponyatiya ustanovki v obshchey i sotsialnoy psikhologii [On the correlation of the concept of attitude in general and social psychology]. G. M. Andreyeva, N. N. Bogomolova (Red.). Teoreticheskiye i metodologicheskiye problemy 
sotsialnoy psikhologii. (s. 143-163). Moskva: Izdatel'stvo Moskovskogo universiteta. [in Russian].

Bruner, Dzh. (2008). Psikhologiya poznaniya. Za predelami neposredstvenno vosprinimayemoy informatsii [The psychology of knowledge. Beyond Directly Perceived Information]. Moskva: Direktmedia Pablishing. [in Russian].

Dem'yanyuk, O. B., \& Kosaryeva, O. I. (2018). Osobly`vosti social`noyi percepciyi u students`koyi molodi (g`enderny`j aspekt) [Features of Social Perception in Student Youth (Gender)]. Psy`xologichny j chasopy `s, 4 (14), 54-67. [in Ukrainian].

Dubovitskaya, T. D. (2014). Sotsialno-pertseptivnaya ustanovka: ponyatiye, funktsii, vidy [Socioperceptual attitude: concept, functions, types]. European social science journal, 1-1 (40), 252-256. Vzyato z https://elibrary.ru/item.asp?id=21540986. [in Russian].

Moskalenko, V. V. (2008). Sotsialna psykholohiia [Social Psychology]. Kyiv: TsUL. [in Ukrainian].

Khudiakova, V. I. (2012). Doslidzhennia kharakterystyk i determinant sotsialnoi pertseptsii u diialnosti menedzhera zakladu [Research of characteristics and determinants of social perception in the activity of the manager of the institution]. Naukovyi visnyk Mykolaivskoho derzhavnoho universytetu im. V. O. Sukhomlynskoho. Psykholohichni nauky, 2.12 (103), 9397. Vziato z http:// nbuv.gov.ua/UJRN/Nvmdups_2014_2_12_37. [in Ukrainian].

\title{
PECULIARITIES OF SOCIAL PERCEPTION IN ADOLESCENT AGE
}

\author{
Victoria Savuliak \\ senior lecturer of the Department \\ of General Psychology and psychological diagnostics \\ of Rivne State University of the Humanities \\ ORCID iD: 0000-0002-5216-6737 \\ DOI https://doi.org/10.35619/prap_rv.vi13.132
}

\begin{abstract}
The political and economic situation of modern social conditions actualized the appeal of researchers to the problem of one of the most important concept of human interaction accuracy and adequacy of social perception. The problem of factors and the peculiarities of social perception was investigated in this article on the basis of available scientific researches of many foreign and domestic scientists. The concept «social perception» is regarded in connection with the concepts «social-perceptual attitude» and «reflection». Socio-perceptual attitude is defined as a predisposition of the subjects of communication to perceive, assess, and act in relation to each other in a certain way. The functions of social-perceptual attitudes are social adaptation (utilitarian function), cognitive function, expression and evaluation, and psychological protection.

The main empirical information for the study was obtained by using: 1) the method "Diagnosis of socio-perceptual attitude of a person to other people» (authors were: Dubovitskaya. Tulitbayeva, Shashkov); 2) the personality inventory "Differential type of reflection» (authors were: Leontev, Lapteva, Osyn, Salykhova). The received date was described and interpreted. The analysis of data makes it possible to explain the age peculiarities of social perception on research of schoolchildren. The article also grounds the perspective of studies of social perception on problem of the individuals in teenage years. The tasks of psychological support and guidance of schoolchildren in their personal and communicative development considered as a main in the activity of the psychological service of educational establishments.

Key words: social perception, socio-perceptual attitude, functions of social-perceptual attitudes, non-verbal communication, systemic reflection, introspection, quasi-reflection, adolescents.
\end{abstract}

Стаття надійшла до редакиії 5.11.2019 p. 